\title{
Molecular Docking Studies of Selected Medicinal Drugs as Dengue Virus-2 Protease Inhibitors
}

(Kajian Mengedok Molekul Dadah Ubatan Terpilih sebagai Perencat Protease Virus-2 Denggi)

\author{
RUFAIDAH OTHMAN, ROZANA OTHMAN, AIDA BAHARUDDIN, NAGASUNDARA RAMANAN RAMAKRISHNAN, \\ NOORSAADAH ABD RAHMAN, ROHANA YUSOF \& SAIFUL ANUAR KARSANI*
}

\begin{abstract}
Dengue is a potentially deadly disease with no effective drug. An in silico molecular docking was performed using Autodock 4.2.6 to investigate the molecular interactions between protease inhibitors, comprising antibiotic derivatives namely doxycycline (3), rolitetracycline (5) and a non-steroidal anti-inflammatory drug (NSAID), meclofenamic acid (4), against the NS2B-NS3 protease from dengue virus-2 (DENV-2). The non-competitive inhibitor (3) showed lower binding energy $(-5.15 \mathrm{kcal} / \mathrm{mol})$ than the predicted competitive inhibitors 4 and 5 (-3.64 and $-3.21 \mathrm{kcal} / \mathrm{mol}$, respectively). Structural analyses showed compound 3 that bound to a specific allosteric site, interacted with Lys74, a significant amino acid residue bonded to one of the catalytic triad, Asp75. Compounds $\mathbf{4}$ and $\mathbf{5}$ showed direct binding with two of the catalytic triad, His51 and Ser135, hence, predicted to be competitive inhibitors.
\end{abstract}

Keywords: Dengue virus-2; docking; inhibitors; NS2B-NS3 protease

ABSTRAK

Denggi adalah sejenis penyakit yang boleh membawa maut dan sehingga kini tiada sebarang ubat untuk merawat penyakit tersebut. Mengedok molekul secara in silico menggunakan Autodock 4.2.6 telah dijalankan untuk mengkaji interaksi molekul antara perencat protease yang terdiri daripada derivatif antibiotik iaitu doxycycline (3) dan rolitetracycline (5) dan dadah anti-radang bukan steroid (NSAID), asid meklofenamik (4), terhadap NS2B-NS3 daripada virus denggi-2 (DENV-2). Perencat tidak-kompetitif (3) menunjukkan tenaga ikatan yang lebih rendah (-5.15 kcal/mol) berbanding sebatian 4 dan 5 (masing-masing -3.64 dan -3.21 kcal/mol). Analisis struktur menunjukkan sebatian 3 yang terikat pada kawasan alosterik, berinteraksi dengan Lys74, iaitu residu asid amino yang terikat dengan salah satu daripada residu triad pemangkinan, Asp75. Sebatian 4 dan 5 pula menunjukkan ikatan langsung dengan dua triad pemangkinan iaitu His51 dan Ser135, justeru diramalkan sebagai perencat kompetitif.

Kata kunci: Mengedok; NS2B-NS3 protease; perencat; virus denggi-2

\section{INTRODUCTION}

Dengue is an infection caused by the dengue virus (DENV) of the Flaviviridae family (Sukupolvi-Petty et al. 2007) and is transmitted by infected female mosquitoes (Bhatt et al. 2013; Kyle \& Harris 2006). Dengue virus has four serotypes (DENV-1 to -4 ) that genetically share $\sim 65 \%$ similarities (Mustafa et al.2015). Although the distinctive DENV-5 (transmitted through non-human primates) has been recently discovered (Normile 2013), DENV-2 is still classified as the world's most epidemiologically and geographically prevalent arboviral disease causing pathogen (Panhuis et al. 2010). Dengue is transmitted in more than 100 tropical and subtropical countries, with $40 \%$ of the populations at risk (Heilman et al.2014). DENV infection causes an acute dengue fever (DF), severe dengue hemorrhagic fever (DHF) and dengue shock syndrome (DSS) (Kadir et al. 2013; Sun \& Kochel 2013). Therapeutic treatments against dengue infections are currently being developed (Amorim et al. 2014; Bhatt et al. 2013; Byrd et al. 2013; Heilman et al. 2014). But until now, there are no licensed antivirals available and prevention has been limited to vector control measures and disease surveillance (Ong 2016; Wan-Norafikah et al. 2012).

DENV is a single-stranded positive-sense RNA genome of $\sim 11 \mathrm{~kb}$ that encodes a single open reading frame (5'-C-prM-E-NS1-NS2A-NS2B-NS3-NS4A-NS4BNS5-3') with three structural and seven non-structural (NS) proteins (Leung et al. 2001). The N-terminal of 180 residues of NS3 is a trypsine-like serine protease (Falgout et al. 1991), which when combined with its co-factor (47 amino acid hydrophilic region of NS2B), is able to cleave the viral polyprotein in cis and trans (Chiu et al. 2007). Disruption of NS2B-NS3 protease inhibits the viral replication (Chen et al. 2014; Wang et al. 2002). This poses NS2B-NS3 protease of DENV-2 as a promising target for antiviral drug design (Tomlinson et al. 2009). 
Several antibiotics had shown to inhibit dengue viruses (Kaptein et al. 2010; Low et al. 2011; Rothan et al. 2014a; Zhang et al. 2009). Antibiotics such as doxycycline (3) and rolitetracycline (5) showed significant inhibitory activity against NS2B-NS3 protease of DENV-2 (Rothan et al. 2014 b, 2013). Furthermore, previous finding had shown that non-steroidal anti-inflammatory drug (NSAID), such as meclofenamic acid (4), was not only used to treat symptoms of dengue infections (Kumar et al.2015) but also to inhibit the NS2B-NS3 protease (Rothan et al.2013). Keeping this in view, in silico molecular docking was performed using Autodock 4.2.6 software to study the interactions of these small molecule compounds (also termed as ligands) with NS2B-NS3 protease of DENV-2. The structural model of the protease, namely DH-1 (Heh et al. 2013), was used as the target protein. Pinostrobin (1) and 4-hydroxypanduratin A (2) were utilized as standard ligands, each representing the non-competitive and competitive inhibitors of NS2B-NS3 protease of DENV-2, respectively (Frimayanti et al. 2011; Heh et al. 2013; Kiat et al. 2006; Othman et al. 2008). Therefore, this study aimed to investigate the binding interactions and search for the best orientation of ligandprotease complex with the lowest binding energy involving the selected antibiotics and NSAID.

\section{MATERIALS AND METHODS}

An Intel Core 2 Duo E6850 $3.00 \mathrm{GHz}$ microprocessor, generated with a random access memory of $8 \mathrm{~GB}$ and an Ubuntu 10.04 Linux operating system were utilized to prepare the docking files, run the docking jobs and analyse the output.

\section{PROTEIN STRUCTURE}

Coordinate file for the 3D homology model of NS2B-NS3 protease of DENV-2, namely DH-1, was retrieved from Heh et al. (2013). This model had been previously minimized, water molecules were removed, non-polar hydrogen atoms were merged, Kollman charges were assigned and the solvation parameters were added.

\section{OPTIMIZATION OF LIGAND STRUCTURES}

The ligands' 3D structures were downloaded from the PubChem webpage (http://www.ncbi.nlm.nih.gov/ pccompound). The ligands' structural energy was stabilized by minimization using the Hyperchem Pro 6.0 software system, employing the PM3 semiempirical method, geometrical optimisation using steepest descent and the operational termination at a maximum setting of 500 cycles or $0.01 \mathrm{kcal} /(\AA \mathrm{mol}) \mathrm{rms}$ gradient. Figure 1 shows the structures of the standard and target ligands.

\section{PREPARATION OF INPUT FILES FOR BLIND DOCKING}

Input files for rigid protein and flexible ligands were prepared using the AutoDock Tools 1.5.6 software (http:// www.mybiosoftware.com/autodock-4-2-3-autodocktools1-5-6-suite-automated-docking-tools.html). Polar and nonpolar hydrogen atoms were individually added and merged to the protein structure. Kollman charges and solvation parameters were determined by default. Gasteiger charges were added to the minimized ligand structures, and all bonds were made rotatable and flexible by allowing the detection of root torsion.

Grid maps with grid spacing of $0.41 \AA$ in the $\mathrm{x}, \mathrm{y}$ and $\mathrm{z}$-dimensions of $126 \times 126 \times 126$ points were set to cover the entire protein. The Lamarckian Genetic Algorithm (LGA) was used to search for the lowest binding energy by implementing local minimization of the genetic algorithm, to enable modification of the gene population (Atilgan \& $\mathrm{Hu}$ 2011). LGA parameters were set as follows: 100 search (docking) runs; population size of 150; 25,000,000

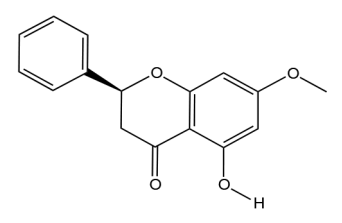

1

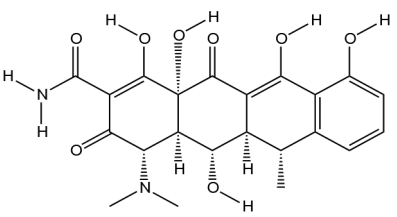

3

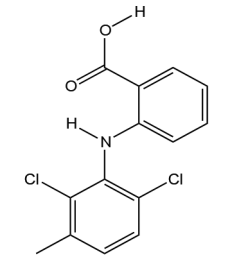

4

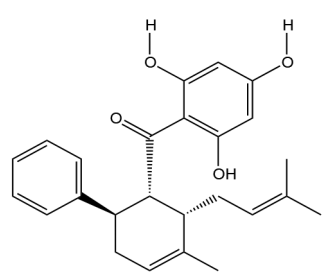

2

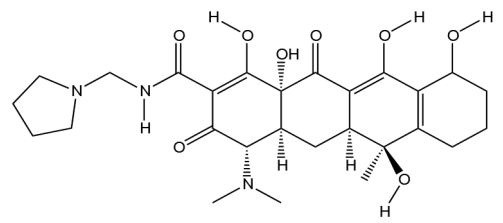

5

FIGURE 1. Molecular structures of ligands used in this study. Standard ligands were pinostrobin (1) (non-competitive inhibitor) and 4-hydroxypanduratin A (2) (competitive inhibitor). Target ligands were doxycycline (3), meclofenamic acid (4) and rolitetracycline (5) 
of energy evaluations; 27,000 numbers of generations; mutation rate of 0.02 and crossover rate of 0.8 . Docking calculation was performed in the AutoDock 4.2.6 software. The output was clustered based on the root-mean-square deviation (RMSD) tolerance of $2.0 \AA$.

\section{ANALYSIS OF DOCKED RESULTS}

The best docked ligand models were selected according to the lowest binding energy that comprised the largest conformational cluster in each binding. Two and threedimensional conformational structures of the ligandprotein complexes were visualized using the Discovery Studio Visualizer 4.5 (http://accelrys.com/products/ collaborative-science/biovia-discovery-studio/) to investigate the binding modes. Hydrophobic interactions were evaluated using the Ligplot program (http://www. ebi.ac.uk/thorntonsrv/software/LigPlus/download.html).

\section{RESULTS AND DISCUSSION}

In this study, in silico investigation showed that medicinal drugs could have potentials as DENV-2 inhibitors. Computational docking studies highlighted that these drugs could bind tightly to the active and allosteric sites of DENV-2 NS2B-NS3 protease. In silico molecular docking is a good tool to predict and match the desired binding site, understanding possible conformation of the compounds and further clarifies the binding interactions in the binding pocket (Grinter \& Zou 2014). Structural homology model built by Heh et al. (2013), namely DH1 , was utilized instead of its crystal structure, due to the missing loop between Ile 76 and Ser85 of the NS2B region (Erbel et al. 2006). DH-1 was previously modelled based on the crystal structure of dengue (PDBid: 2FOM) and West Nile (2FP7) viruses with $89 \%$ of its residues were located in the most favored region of the Ramachandran plot (Heh et al. 2013). By using 2FP7 as the template, Thr77, Ile78,
Ser79, Glu80 Asp81, Gly82, Ser83 and Met84 were added to merge the existing gap. Blind docking was applied to the current work using the complete structural model of the target protein (DH-1). The docking methodology was validated using the standard ligands, pinostrobin (1) and 4-hydroxypanduratin A (2), each representing the noncompetitive and competitive inhibitors, respectively.

Previous in vitro studies had highlighted the inhibitory potentials for compounds $\mathbf{3 , 4}$ and $\mathbf{5}$ (Table 1), with compound $\mathbf{3}$ reported to be non-competitive (Rothan et al. 2014b, 2013). Therefore, the current docking study was conducted not only to determine the ligand poses in the binding sites and the interactions involved, but also to determine the sites to which compounds $\mathbf{4}$ and $\mathbf{5}$ were bound and to further validate the inhibitory characteristic of compound 3. The target protein (DH-1) was assigned to be rigid. Meanwhile, the ligands were made flexible by retaining the structural rotatable bonds (Table 1), which would increase the number of ligands' conformations and the probability to bind to the potential binding site (Atkovska et al. 2014; Hetényi \& Spoel 2006). Blind docking was used to maneuver the ligands over the entire surface of the protein and their tendency to bind to the allosteric and/or active sites were observed. Although prediction of docked complex using blind docking is difficult, it allows the ligand to bind the actual binding site rather than to the nonspecific and/or energetically unfavorable sites inside the protein (Hetényi \& Spoel 2006).

\section{SCORING FUNCTION}

The scoring function for the docking run is presented as the binding energy, $\mathrm{E}_{\text {bind }}$ (Table 1). The non-competitive inhibitors (1 and $\mathbf{3}$ ) are top in the ranking (low binding energy values, $\mathrm{E}_{\text {bind }}$ ) followed by the competitive compounds $(\mathbf{2}, \mathbf{4}$ and $\mathbf{5})$. Compound $\mathbf{3}$ shows the lowest $\mathrm{E}_{\text {bind }}$ value $(-5.15 \mathrm{kcal} / \mathrm{mol})$ indicating the highest binding affinity (Datar \& Jadhav 2015) towards NS2B-NS3

TABLE 1. Relationship between the predicted binding energies obtained from docking runs and the experimental inhibitory activities reported from previous studies

\begin{tabular}{|c|c|c|c|c|c|c|c|}
\hline \multicolumn{4}{|c|}{ Docking } & \multicolumn{4}{|c|}{ Experimental } \\
\hline \multirow[t]{2}{*}{ ID } & \multirow{2}{*}{$\begin{array}{l}\text { No. of } \\
\text { atoms }\end{array}$} & \multirow{2}{*}{$\begin{array}{l}\text { No. of } \\
\text { rotatable bonds }\end{array}$} & \multirow{2}{*}{$\begin{array}{c}\mathrm{E}_{\text {bind }}^{\mathrm{a}} \\
(\mathrm{kcal} / \mathrm{mol})\end{array}$} & \multirow{2}{*}{$\begin{array}{c}\mathrm{IC}_{50}^{\mathrm{b}} \\
(\mu \mathrm{g} / \mathrm{ml})\end{array}$} & \multirow{2}{*}{$\begin{array}{c}K i^{\mathrm{c}} \\
(\mu \mathrm{M})\end{array}$} & \multicolumn{2}{|c|}{$\%$ Inhibition $^{6}$} \\
\hline & & & & & & $25 \mu \mathrm{M}$ & $100 \mu \mathrm{M}$ \\
\hline 1 & 34 & 3 & -5.33 & $90.48^{1}$ & $\begin{array}{l}348 \pm 70^{2} \\
345 \pm 70^{3}\end{array}$ & \multicolumn{2}{|c|}{ NA } \\
\hline 2 & 57 & 8 & -4.45 & $40^{3}$ & $21^{3}$ & NA & NA \\
\hline 3 & 56 & 8 & -5.15 & $\begin{array}{c}52.3 \pm 6.2\left(\text { at } 37^{\circ} \mathrm{C}\right)^{4} \\
26.7 \pm 6.2\left(\text { at } 40^{\circ} \mathrm{C}\right)^{4} \\
55.6^{6}\end{array}$ & $55.6 \pm 5.7^{5}$ & $35.6 \pm 3.2$ & $53.8 \pm 2.8$ \\
\hline 4 & 30 & 4 & -3.64 & NA & NA & $19.4 \pm 2.2$ & $43.0 \pm 1.4$ \\
\hline 5 & 71 & 10 & -3.21 & $67.1^{6}$ & NA & $32.8 \pm 2.6$ & $38.9 \pm 2.9$ \\
\hline
\end{tabular}

${ }^{a}$ Lowest binding energy. ${ }^{\mathrm{b}}$ Half maximal inhibitory concentration. ${ }^{\mathrm{c}}$ Inhibition constant.

${ }^{1}$ Othman et al. (2008); ${ }^{2}$ Heh et al. (2013); ${ }^{3}$ Kiat et al. (2006); ${ }^{4}$ Rothan et al. (2014b); ${ }^{5}$ Rothan et al. (2013); ${ }^{6}$ Yang et al. (2007).

$\mathbf{1}=$ Pinostrobin; $\mathbf{2}$ = 4-hydroxypanduratin A; $\mathbf{3}=$ Doxycycline; $\mathbf{4}=$ Meclofenamic acid; $\mathbf{5}=$ Rolitetracycline. NA = Not available 
protease of DENV-2 compared to compounds 4 and $\mathbf{5}$ (-3.64 and $-3.21 \mathrm{kcal} / \mathrm{mol}$, respectively).

In general, the trend for the computed $\mathrm{E}_{\text {bind }}$ values did not correlate with the trend of the experimentally determined $\mathrm{IC}_{50}$ and $\mathrm{Ki}$ values obtained from previous studies (Table 1). To explain the experimental observation, in depth analyses of the binding interactions was performed.

\section{NON-COMPETITIVE AND COMPETITIVE INHIBITORS}

Figure 2 shows the top ranking docked poses of the ligands and standards. The standard (compound $\mathbf{1}$ ) and compound $\mathbf{3}$ bound to the same allosteric site, which is proximal to the protease active site. This result correlates with findings reported by Rothan et al. (2013), which showed compound 3 as a non-competitive inhibitor of DENV-2 NS2B-NS3 protease. On the other hand, the inhibitory characteristic for compounds $\mathbf{4}$ and $\mathbf{5}$ was not described (Rothan et al. 2013). In the current docking study, both compounds were predicted to be competitive inhibitors since they docked to the active site of the protease. As shown in Figure 2, compounds $\mathbf{4}$ and $\mathbf{5}$ bound to the same (active) site as with the standard (compound 2; competitive inhibitor) located close to His51 and Ser135.

Tables 2 and 3 list the amino acid residues in the binding site that interact with the ligands. As can be seen, some key residues interacted with both the standard and tested ligands, thus underlining the mode of inhibition of these ligands. For the non-competitive inhibition, out of the twenty-two amino acid residues in the binding site that are involved in the interactions with the ligands, five residues were involved in binding to compounds $\mathbf{1}$ and $\mathbf{3}$, namely Lys74, Ala164, Ile165, Ala166, and Asn167. These residues are located at a specific region in the allosteric pocket (proximal to the catalytic triad), thus confirming the non-competitive inhibitory characteristic of compound $\mathbf{3}$. Additionally, Lys74 is a crucial residue in the allosteric site (Heh et al. 2013; Othman et al. 2008) and in this study, it is involved in the hydrophobic interaction with both the standard (1) and target (3) ligands (Table 3 and Figure 4).

Meanwhile, out of the sixteen residues that interacted with the standard (2) and compounds $\mathbf{4}$ and $\mathbf{5}$ ligands, ten residues (Phe130, Thr134, Tyr150, Gly151, Asn152, Gly153, Val155, Tyr161, and two of the catalytic triad, His51 and Ser135), interact with all the three ligands, underlining the competitive inhibitory characteristics of compounds $\mathbf{4}$ and $\mathbf{5}$.

\section{BINDING INTERACTIONS}

Figure 3 shows the poses and the non-covalent interactions involved between the ligands and the protease-binding site. Hydrogen bond donors (HBD) and acceptors (HBA)

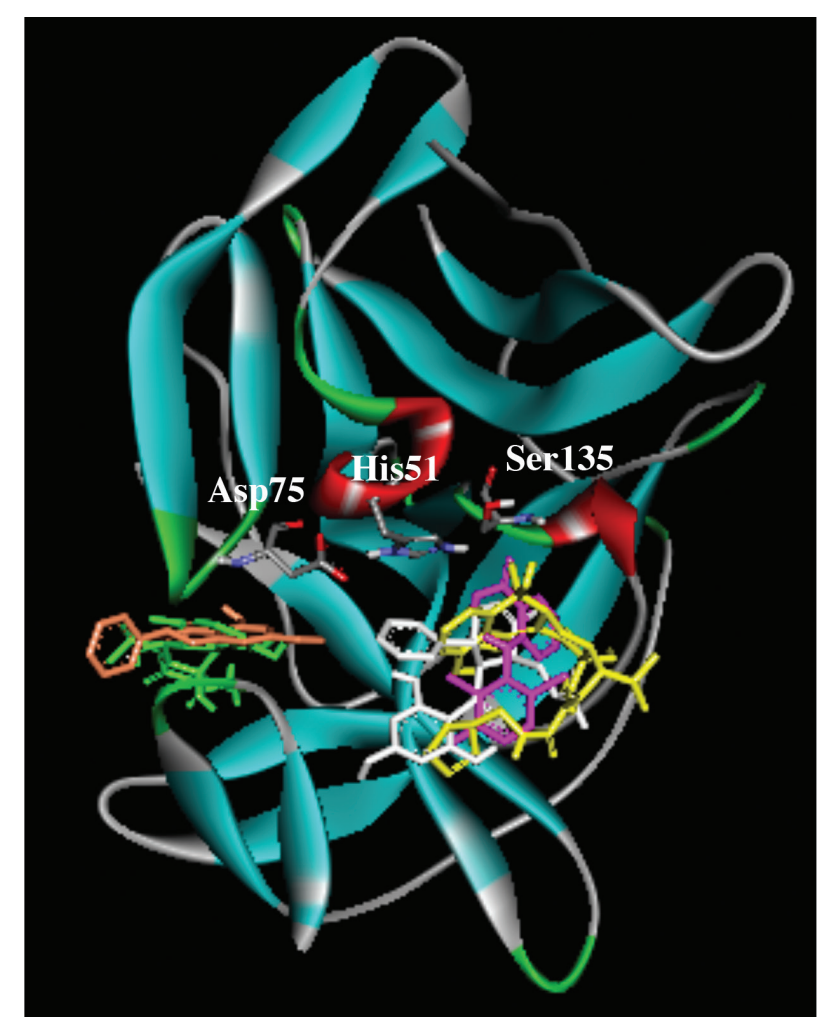

FIGURE 2. Three-dimensional structure highlighting the best binding mode of ligands (sticks) in NS2B-NS3 protease of DENV-2 (ribbons). NS2B is highlighted in moss green while NS3 protease in ribbons with elementary color. Compounds $\mathbf{1}$ (orange) and $\mathbf{2}$ (white) are the standard ligands, while compounds $\mathbf{3}, \mathbf{4}$ and $\mathbf{5}$ are displayed in green, pink and yellow, respectively. Residues His51, Asp75 and Ser135 (elementary-colored sticks) are the catalytic triad. The image was generated using the Discovery Studio Visualizer 4.5 
and the length of H-bonds are further clarified in Table 2 . The (non-competitive) compound $\mathbf{3}$ involved the most number of H-bonds with Asn167, Trp89, Thr122 and Ile165 in the allosteric site. While the (competitive) compound 4 exhibited $\mathrm{H}$-bonding interactions with one of the catalytic triad (His51) and Gly151, compound 5 formed H-bonds with Gly151, in addition to Phe130, Gly153 and Tyr161. There were seven H-bonds in compound $\mathbf{3}$ that involved the amino and hydroxyl groups (HBD) (Table 2). Other noncovalent interactions were the pi-H-bonding with Asn167, carbon-oxygen dipole-dipole interaction with Glu88 (Table 2) and van der Waals interactions with Glu91, Thr120, Gly124, Ala164, Ala166 (Table 3). Pi-H-bond is a point to pi-plane interactions that allows more conformations and larger energy range ( 2 to $7 \mathrm{kcal} / \mathrm{mol}$ ) than the conventional H-bond and electrostatic interactions (Du et al. 2013). The phenolic ring of compound $\mathbf{3}$ formed a pi-H-bond with the hydrogen from the amino group of Asn167. On the other hand, no pi-H-bond was observed involving compounds $\mathbf{4}$ and $\mathbf{5}$. This suggested why compound $\mathbf{3}$ had the lowest binding energy among the three target ligands.

Compound 5, which was predicted to be competitive inhibitor, involved five H-bonding while compound 4 (competitive inhibitor) showed only three (Table 2 and Figure 3). However, compound 4 showed a higher scoring function (lower $\mathrm{E}_{\text {bind }}$ ) which could be attributable to the two H-bonds that was formed between its carboxyl oxygen atom with the hydrogen atom of the amino group from one of the catalytic triad, His51 (Duax et al. 2005) (Table 2 and Figure 3, left). The carboxyl group had a greater number of dipoles contributed from the strongly polarized carbonyl and hydroxyl functional groups, which added to the compound's strong binding affinity (Lifson et al. 1979). On the contrary, H-bonding with compound 5 involved solely the individual carbonyl and hydroxyl groups, respectively (Table 2).

From Table 3, van der Waals interaction was also observed in both compounds $\mathbf{4}$ and $\mathbf{5}$, involving Ser135 (one of the catalytic triad) and other residues namely Thr134, Tyr150 and Val154. Individually, other residues involved in van der Waals interaction with compound 4 were Phe130, Ser131, Pro132, Asn152 and Gly153 and Asp129 with compound 5. Pi interaction such as alkylpi was observed between compound 4 with Val155 and Tyr161. Meanwhile, two benzene rings in compound 4 appeared to have a T-shaped pi-pi stacking interaction with Tyr161. For compound 5, both cation-pi and pi-pi stacking interactions were engaged with His51 (from the catalytic triad), which were also clearly observable in the 3D structure (Figure 3, left).

TABLE 2. Residues involved in the H-bonding, pi-H bonding and dipole-dipole interactions in the ligand-protease complex, as determined using Discovery Studio 4.5 Visualizer

\begin{tabular}{|c|c|c|c|c|c|c|c|}
\hline \multirow[t]{3}{*}{ ID } & \multicolumn{5}{|c|}{ H-bond } & \multirow[t]{3}{*}{ Pi-H-bond } & \multirow[t]{3}{*}{ Dipole-dipole } \\
\hline & \multicolumn{2}{|c|}{ Donors } & \multicolumn{2}{|c|}{ Acceptors } & \multirow{2}{*}{$\frac{\text { Distances }}{(\AA)}$} & & \\
\hline & Atoms & F. groups & Atoms & F.groups & & & \\
\hline \multirow[t]{3}{*}{1} & B:Asn152:HD21 & $-\mathrm{NH}$ & $\mathrm{O} 4$ & $-\mathrm{C}-\mathrm{O}-\mathrm{C}-$ & 1.93527 & \multirow[t]{3}{*}{ NA } & \multirow[t]{3}{*}{ C20 - B:Asn152:O } \\
\hline & B:Asn167:HN & $-\mathrm{NH}$ & $\mathrm{O} 3$ & $-\mathrm{OH}$ & 1.83825 & & \\
\hline & $\mathrm{H} 31$ & $-\mathrm{OH}$ & B:Asn167:O & $-\mathrm{C}=\mathrm{O}$ & 1.90466 & & \\
\hline \multirow[t]{3}{*}{2} & B:Gly153: HN & $-\mathrm{NH}$ & $\mathrm{O} 3$ & $-\mathrm{OH}$ & 1.85400 & \multirow[t]{3}{*}{ NA } & \multirow[t]{3}{*}{ A:Ser83:CB - Ob1 } \\
\hline & $\mathrm{H} 56$ & $-\mathrm{OH}$ & B:Asn152:OD1 & $-\mathrm{C}=\mathrm{O}$ & 1.70581 & & \\
\hline & H57 & $-\mathrm{OH}$ & A:Met84:O & $-\mathrm{C}=\mathrm{O}$ & 2.10307 & & \\
\hline \multirow[t]{7}{*}{3} & B:Asn167:HD22 & $-\mathrm{NH}$ & $\mathrm{O} 3$ & $-\mathrm{C}=\mathrm{O}$ & 1.89173 & \multirow[t]{7}{*}{ B:Asn167:HN - b } & \multirow[t]{7}{*}{ C28 - B:Glu88:OE1 } \\
\hline & B:Asn167:HD22 & $-\mathrm{NH}$ & $\mathrm{O} 5$ & $-\mathrm{OH}$ & 2.63800 & & \\
\hline & H54 & $-\mathrm{NH}$ & B:Trp89:O & $-\mathrm{C}=\mathrm{O}$ & 2.38811 & & \\
\hline & H50 & $-\mathrm{OH}$ & B:Thr122:O & $-\mathrm{C}=\mathrm{O}$ & 2.06387 & & \\
\hline & $\mathrm{H} 42$ & $-\mathrm{OH}$ & B:Thr122:O & $-\mathrm{C}=\mathrm{O}$ & 1.64877 & & \\
\hline & H51 & $-\mathrm{OH}$ & B:Ile165:O & $-\mathrm{C}=\mathrm{O}$ & 1.90640 & & \\
\hline & H56 & $-\mathrm{OH}$ & B:Ile165:O & $-\mathrm{C}=\mathrm{O}$ & 2.35336 & & \\
\hline \multirow[t]{3}{*}{4} & B:His51:HE2 & $-\mathrm{NH}$ & $\mathrm{O} 4$ & $-\mathrm{C}=\mathrm{O}^{*}$ & 2.11584 & \multirow[t]{3}{*}{ NA } & \multirow[t]{3}{*}{ NA } \\
\hline & B:His51:HE2 & $-\mathrm{NH}$ & $\mathrm{O} 3$ & $-\mathrm{OH}^{*}$ & 2.21816 & & \\
\hline & H30 & $-\mathrm{OH}^{*}$ & B: Gly151:O & $-\mathrm{C}=\mathrm{O}$ & 2.31655 & & \\
\hline \multirow[t]{5}{*}{5} & $\mathrm{H} 47$ & $-\mathrm{OH}$ & B:Phe130:O & $-\mathrm{C}=\mathrm{O}$ & 1.78001 & \multirow[t]{5}{*}{ NA } & \multirow[t]{5}{*}{ B:Asn 152:CA - O7 } \\
\hline & H57 & $-\mathrm{OH}$ & B:Gly151:O & $-\mathrm{C}=\mathrm{O}$ & 2.24901 & & \\
\hline & H57 & $-\mathrm{OH}$ & B:Tyr161:OH & $-\mathrm{OH}$ & 2.18301 & & \\
\hline & $\mathrm{H} 71$ & $-\mathrm{OH}$ & B:Tyr161:OH & $-\mathrm{OH}$ & 2.00355 & & \\
\hline & B:Gly153:HN & $-\mathrm{NH}$ & $\mathrm{O} 7$ & $-\mathrm{OH}$ & 2.72705 & & \\
\hline
\end{tabular}

* Carbonyl $(-\mathrm{C}=\mathrm{O})$ and hydroxyl $(-\mathrm{OH})$ groups from the same carboxyl $(-\mathrm{COOH})$ functional group.

$\mathbf{1}=$ Pinostrobin $; \mathbf{2}=$ 4-hydroxypanduratin A; $\mathbf{3}=$ Doxycycline; $\mathbf{4}=$ Meclofenamic acid $\mathbf{5}=$ Rolitetracycline. F. groups = Functional groups; $-=$ Interacts with. b1 = Benzene $1 ; \mathrm{A}=\mathrm{NS} 2 \mathrm{~B}$ chain in the NS2B-NS3 protease; $\mathrm{B}=$ NS3 protease chain in the NS2B-NS3 protease; NA = Not available. For H-bond donors and acceptors, the functional group from where the atom derived is mentioned; and the atoms that are displayed as individuals are indicating contributors from the ligand. 
TABLE 3. Residues involved in pi-effects, van der Waals forces and hydrophobic interactions

\begin{tabular}{|c|c|c|c|c|c|c|c|}
\hline ID & Alkyl-pi & Sigma-pi & Cation-pi & Pi-pi stacking & T-shaped pi-pi & van der Waals & Hydrophobic \\
\hline 1 & $\begin{array}{l}\text { B:Lys73 - b1 } \\
\text { B:Lys74 - b1 } \\
\text { B:Lys74 - b2 } \\
\text { A:Ile78 - b1 } \\
\text { B:Ala164 - b1 } \\
\text { B:Ala166 - b2 }\end{array}$ & NA & NA & NA & NA & $\begin{array}{l}\text { B:Ile165 } \\
\text { B:Asp71 } \\
\text { A:Met84 }\end{array}$ & $\begin{array}{l}\text { B:Asp71 } \\
\text { B:Lys73 } \\
\text { B:Lys74 } \\
\text { A:Ile78 } \\
\text { A:Met84 } \\
\text { B:Ala164 } \\
\text { B:Ala166 }\end{array}$ \\
\hline 2 & $\begin{array}{l}\text { B:His51 - chy } \\
\text { B:Tyr150 - C14 } \\
\text { B:Tyr161 - C26 }\end{array}$ & C25 - B:Tyr161 & NA & NA & B:His51 - b2 & $\begin{array}{l}\text { B:Asp75 } \\
\text { B:Asp129 } \\
\text { B:Phe130 } \\
\text { B:Thr134 } \\
\text { B:Ser135 } \\
\text { B:Gly151 } \\
\text { B:Gly153 } \\
\text { B:Val155 }\end{array}$ & $\begin{array}{l}\text { B:His51 } \\
\text { B:Asp75 } \\
\text { A:Ser83 } \\
\text { B:Asp129 } \\
\text { B:Phe130 } \\
\text { B:Tyr150 } \\
\text { B:Gly151 } \\
\text { B:Val155 } \\
\text { B:Tyr161 }\end{array}$ \\
\hline 3 & NA & NA & NA & NA & NA & $\begin{array}{l}\text { B:Glu91 } \\
\text { B:Thr120 } \\
\text { B:Gly124 } \\
\text { B:Ala164 } \\
\text { B:Ala166 }\end{array}$ & $\begin{array}{l}\text { B:Lys74 } \\
\text { B:Glu88 } \\
\text { B:Ile123 } \\
\text { B:Ala164 } \\
\text { B:Ala166 }\end{array}$ \\
\hline 4 & $\begin{array}{l}\text { B:Val155 - C16 } \\
\text { B:Tyr161 - Cl1 } \\
\text { B:Tyr161 - C16 }\end{array}$ & NA & NA & NA & $\begin{array}{l}\text { B:Tyr161 - b1 } \\
\text { B:Tyr161 - b2 }\end{array}$ & $\begin{array}{l}\text { B:Phe130 } \\
\text { B:Ser131 } \\
\text { B:Pro132 } \\
\text { B:Thr134 } \\
\text { B:Ser135 } \\
\text { B:Tyr150 } \\
\text { B:Asn152 } \\
\text { B:Gly153 } \\
\text { B:Val154 }\end{array}$ & $\begin{array}{l}\text { B:Phe130 } \\
\text { B:Ser131 } \\
\text { B:Thr134 } \\
\text { B:Ser135 } \\
\text { B:Tyr150 } \\
\text { B:Gly153 } \\
\text { B:Val154 } \\
\text { B:Val155 } \\
\text { B:Tyr161 }\end{array}$ \\
\hline 5 & NA & NA & B:His51:NE2 - b & B:His51 - b & NA & $\begin{array}{l}\text { B:Asp129 } \\
\text { B:Thr134 } \\
\text { B:Ser135 } \\
\text { B:Tyr150 } \\
\text { B:Val154 }\end{array}$ & $\begin{array}{l}\text { B:His51 } \\
\text { B:Pro132 } \\
\text { B:Ser135 } \\
\text { B:Asn152 } \\
\text { B:Gly153 } \\
\text { B:Val154 } \\
\text { B:Val155 }\end{array}$ \\
\hline
\end{tabular}

$\mathbf{1}=$ Pinostrobin $\mathbf{2}=4$ hydroxypanduratin A; $\mathbf{3}=$ Doxycycline $\mathbf{4}=$ Meclofenamic acid $; \mathbf{5}=$ Rolitetracycline $-\mathbf{-}=$ Interacts with $\mathrm{b}=\mathrm{Benzene} ; \mathrm{b} 1=\mathrm{Benzene}$ 1; $\mathrm{b} 2=\mathrm{Benzene}$ 2 ; chy = Cyclohexenyl scaffold; cho = Cyclohexanone; chol = Cyclohexenol scaffold; py = Pyrrolidine; $\mathrm{A}=\mathrm{NS} 2 \mathrm{~B}$ chain in the NS2B-NS3 protease; $\mathrm{B}=\mathrm{NS} 3$ pro chain in the NS2B-NS3 protease; NA = Not available. Atoms stated individually are indicating contributors from the ligand

A 2D visual inspection of hydrophobic interaction is depicted in Figure 4. As previously mentioned, the noncompetitive inhibitor (3) exhibited hydrophobic interaction with Lys74, a key residue in the protease allosteric site (Othman et al. 2008) and with Glu88, Ile123, Ala164 and Ala166. Likewise, the standard ligand (1) also exhibited hydrophobic interaction with Lys74, Ala164 and Ala166, and additionally with Asp71, Lys73, Ile78 and Met84. In the case of the competitive ligands $\mathbf{4}$ and $\mathbf{5}$, both exhibited hydrophobic interactions with one of the catalytic triad, Ser135 and with Gly153, Val154 and Val155. Additionally, compound 4 also interacted with Phe130, Ser131, Thr134, Tyr150 and Tyr161, while compound $\mathbf{5}$ interacted with Pro132, Asn 152 and a residue from the catalytic triad, His51. Among these residues, Phe130, Tyr150, Val155,
Tyr161 and His51 (a catalytic triad) showed hydrophobic interactions with the standard competitive inhibitor (2). Meanwhile, Asp75, Ser83, Asp129 and Gly151 were additional residues found in the standard (2) but not in compounds $\mathbf{4}$ and $\mathbf{5}$.

\section{BINDING POCKET AND ELECTROSTATIC POTENTIAL SURFACE (EPS)}

The binding pocket of NS2B-NS3 protease to where all compounds 3, 4 and 5 were bound, is divided into two; the left and right regions (Figure 5). For compound $\mathbf{3}$, the cyclohexenone scaffold (with the amide and tertiary amine functional groups) and a tetrahydroquinone scaffold are resided in the left cleft, while the right cleft was filled with the cyclohexanol and phenolic scaffolds. Both compounds 

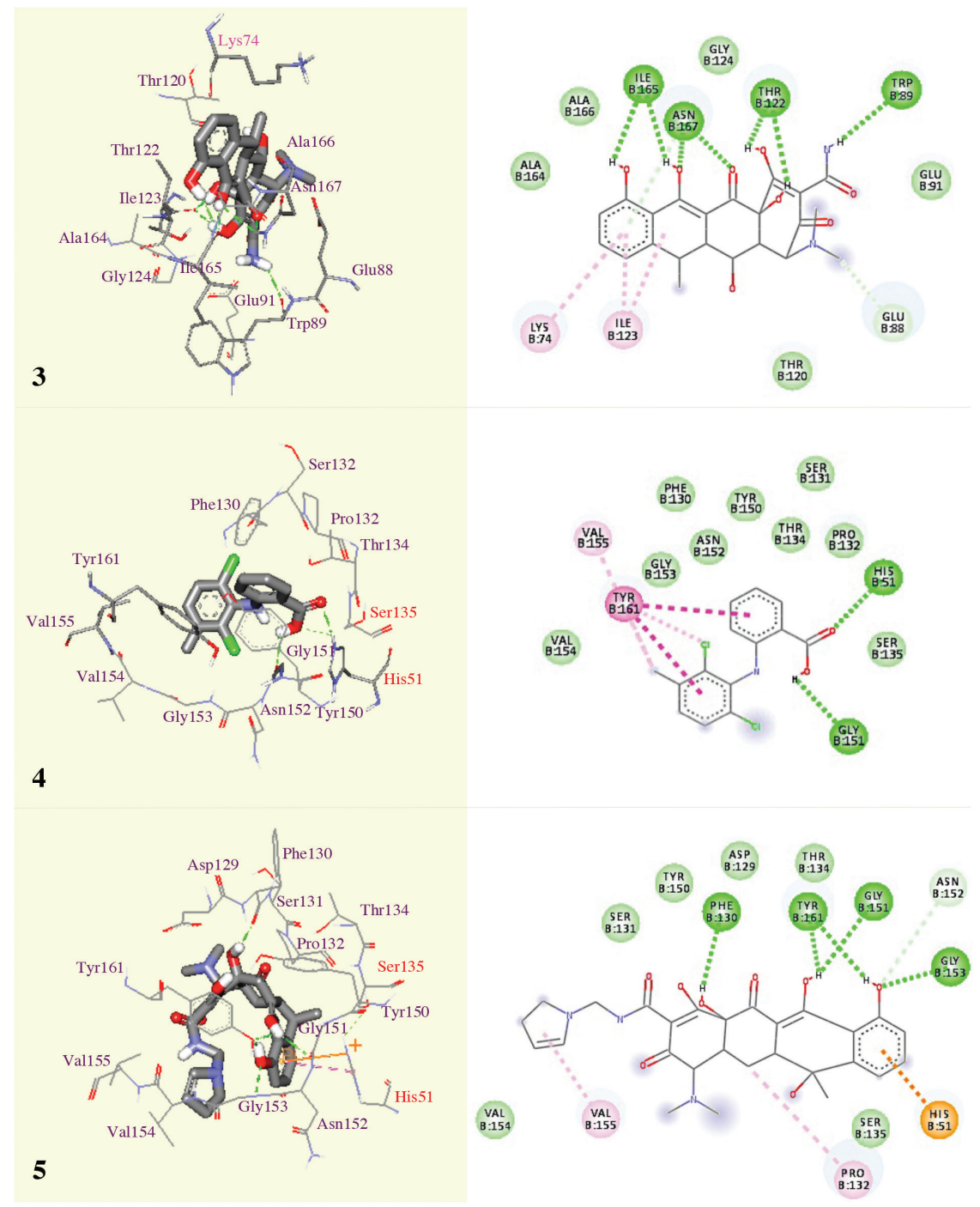

FIGURE 3. The 3D (left) and 2D (right) structural views of ligand-binding site interactions. The 3D structures display H-bond interactions (green dashed lines) between compounds $\mathbf{3 , 4}$ and $\mathbf{5}$ (sticks) and the binding site (wire frames). A clear observation of cation-pi (orange line) and pi-pi stacking (pink dashed line) can be observed only in compound $\mathbf{5}$. Main residues from both the allosteric site, Lys74 (pink) and the catalytic triad, His51 and Ser135 (orange) are observed. Simplified visualization is illustrated in 2D, which displays the H-bonding (dark green circles associated with the green dashed lines); van der Waals forces (medium light green circles); carbon-oxygen dipole-dipole interaction (light green circles with dashed lines); alkyl-pi interactions (light pink circles with dashed lines); T-shaped pi-pi stacking and (parallel) pi-pi stacking (both indicated with dark pink circles); cation-pi interaction (orange circle). The blue halo surrounding the interacting residues represents the solvent accessible surface that is proportional to its diameter. Images were generated using Discovery Studio Visualizer 4.5

4 and 5 were inclined towards the left region of the binding pocket, leaving a more spacious area to the right region of the pocket (Figure 5, top). The dichlorotoluene ring in compound $\mathbf{4}$ is observed to be occupying the centre of the binding site, while the benzoic acid moiety resided in the top region of the binding site (Figure 5, top). Comparatively, compound 5 occupied the whole binding pocket with both the terminal pyrrolidine and phenolic rings were bent towards the left side of the cleft (Figure 5, top). Meanwhile, the right cleft was filled with most part of the 4-methylcyclohexen-1,4-diol moiety, the cyclohexanone and cyclohexenone scaffolds with the tertiary amine and hydroxyl functional groups. Additionally, the amide group was found situated in the middle of the binding clefts.
The shape complementary of a drug with its binding pocket is important in determining the affinity and the specificity of the drug (Bespamyatnikh et al. 2004). The best shape complementary could be seen with compound $\mathbf{3}$, where the binding pocket was narrow and deep, indicating a stronger ligand affinity (Fukunishi \& Nakamura 2011), as compared to the more shallow and broader pocket enclosing compounds $\mathbf{4}$ and $\mathbf{5}$. Looking at the connolly surface representation of the binding sites the affinity of compound $\mathbf{3}$ was further enhanced by the large distribution of the negative electrostatic potential surface (EPS) (dark red) (Atkins \& Paula 2014) on the left side of the binding pocket, which attracted the tertiary amine functional group (the upper region) and the amide side chain (the left region) 
3

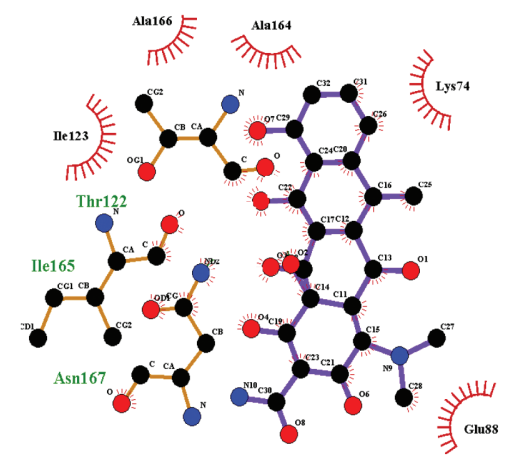

4

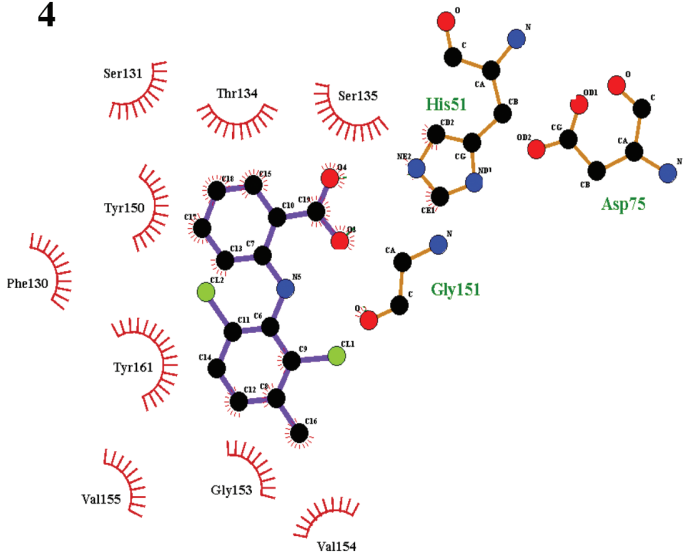

5

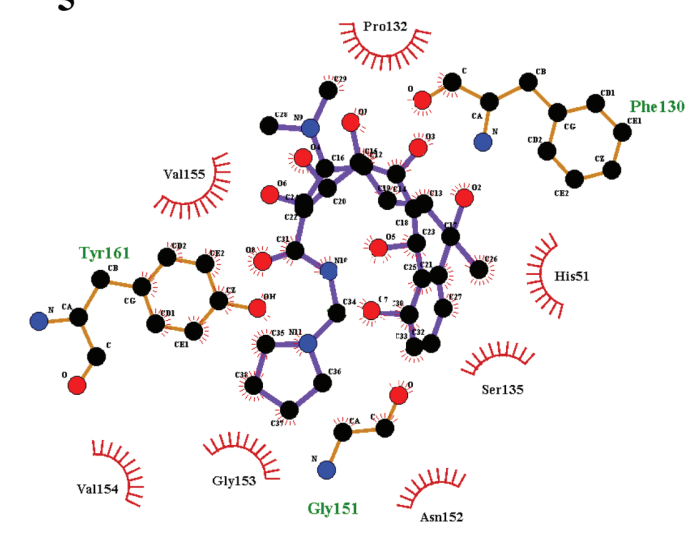

FIGURE 4. Hydrophobic interactions between compounds $\mathbf{3}, \mathbf{4}$ and $\mathbf{5}$, with the binding site. The 2D ligand structures are represented as thick purple sticks and the residues of the binding site as brown sticks and and those involved in the hydrophobic interactions are depicted with the red eye-lashes. Images were generated using the Ligplot program

(Figure 5, left and top). On the contrary, for compounds 4 and 5, it could be observed that there was a smaller area of negative EPS towards the right side of the binding pocket. As a result, the dichlorotoluene ring in compound 4 could be repelled and bent towards the left side of the cleft (Figure 5, all views). But in the case of compound $\mathbf{5}$, this negative EPS could have attracted the tertiary amine functional group (Figure 5, right and top). Generally, compounds $\mathbf{4}$ and $\mathbf{5}$ bound to the same pocket, indicating similar core of EPS that could possibly explain their similar values for $\mathrm{E}_{\text {bind }}$ (Kellenberger et al. 2008). However, as discussed, each compound had its own favourable binding interactions, which when combined with the binding pocket shape complementary, may lead to the different levels of inhibition activity.

\section{CONCLUSION}

From the in silico docking study, doxycycline (3) was shown to bind to an allosteric site, underlining its noncompetitive mode of inhibition of the NS2B-NS3 protease of DENV-2. One of the interactions involved Lys74, a key residue for non-competitive inhibitors to interact with. Meclofenamic acid (4) and rolitetracycline (5) were predicted as competitive inhibitors based on their interactions with His51 and Ser135, two amino acid residues which comprised the protease catalytic triad. Higher binding affinity for compound $\mathbf{3}$ was observed to match with its deep binding pocket, while compounds with lower binding affinities (4 and 5) showed a shallow binding pocket. The presence of a pi-H-bond with Asn167, together with the deep binding pocket, could explain for the high binding affinity in compound $\mathbf{3}$. The lower binding affinity observed with compounds $\mathbf{4}$ and $\mathbf{5}$ could be attributable to their binding to the shallow binding pocket. Both compounds interacted with His51, but compound 4 involved H-bonding with this residue, which could explain its higher binding affinity compared to compound $\mathbf{5}$. In conclusion, this study has provided further understanding on the binding mode and interactions of these inhibitors with DENV-2 protease, which may be useful in the development of potential anti-dengue drugs.

\section{ACKNOWLEDGEMENTS}

We would like to acknowledge the computational group led by Assoc. Prof. Dr. Rozana Othman for the workstations, softwares and the financial support through grant No. RP002-2012B under the UMRG Programme. 


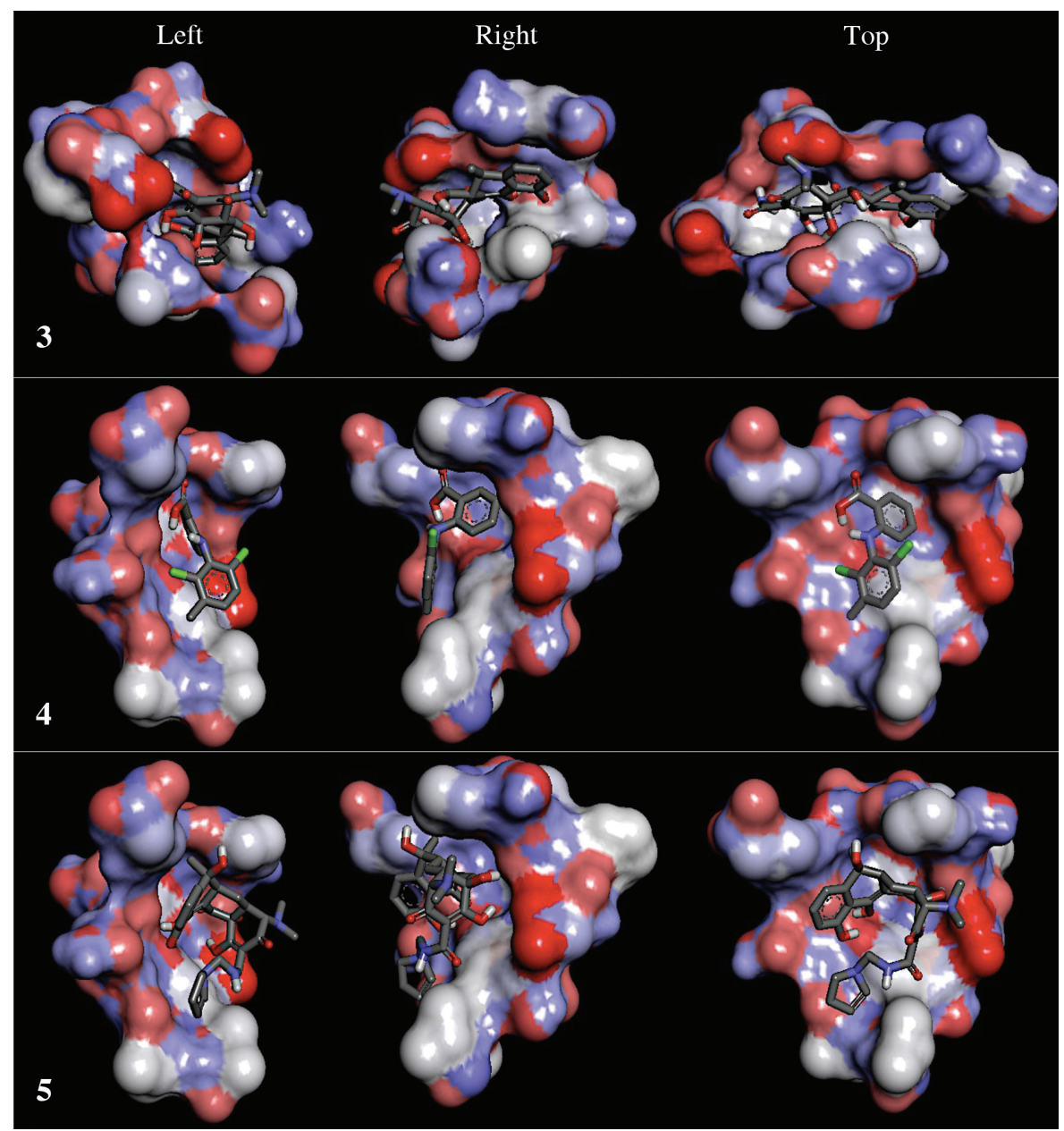

FIGURE 5. Connolly surface representation of the electrostatic potential in the binding pocket of DENV-2 NS2B-NS3 protease complexed with ligands. Each ligand, 3, $\mathbf{4}$ and $\mathbf{5}$ are shown as sticks with multiple views from the right, left and top. Connolly surface with red color indicates negative potential, blue surface represents positive potential and white surface for neutral groups. The images were generated using the Discovery Studio Visualizer 4.5

\section{REFERENCES}

Amorim, J., Alves, R., Boscardin, S. \& Ferreira, L. 2014. The dengue virus non-structural 1 protein: risks and benefits. Virus Research 181(53-60): 53-60.

Atilgan, E. \& Hu, J. 2011. Improving protein docking using sustainable genetic algorithms. International Journal of Computer Information Systems and Industrial Management Applications 3: 248-255.

Atkovska, K., Samsonov, S.A., Paszkowski-Rogacz, M. \& Pisabarro, M.T. 2014. Multipose binding in molecular docking. International Journal of Molecular Sciences 15(2): 2622-2645.

Bespamyatnikh, S., Edelsbrunner, V.C.H. \& Rudolph, J. 2004. Accurate Protein Docking by Shape Complementarity Alone. https://users.cs.duke.edu/ edels/Papers/2003-R-09AccurateProteinDocking.pdf

Bhatt, S., Gething, P.W., Brady, O.J., Messina, J.P., Farlow, A.W., Moyes, C.L., Drake, J.M., Brownstein, J.S., Hoen, A.G., Sankoh, O., Myers, M.F., George, D.B., Jaenisch, T., Wint, G.R.W., Simmons, C.P., Scott, T.W., Farrar, J.F. \& Hay, S.I. 2013. The global distribution and burden of dengue. Nature 496(7446): 504-507.

Byrd, C., Dai, D., Grosenbach, D., Berhanu, A., Jones, K., Cardwell, K., Schneider, C., Wineinger, K.A., Page, J.M.,
Harver, C., Stavale, E., Tyavanagimatt, S., Stone, M.A., Bartenschlager, R., Scaturro, P., Hruby, D.E. \& Jordan, R. 2013. A novel inhibitor of dengue virus replication that targets the capsid protein. Antimicrobial Agents and Chemotheraphy 57(1): 15-25.

Chen, W.N., Loscha, K.V., Nitsche, C., Graham, B. \& Otting, G. 2014. The dengue virus NS2B-NS3 protease retains the closed conformation in the complex with BPTI.FEBS Letters 588(14): 2206-2211.

Chiu, M., Shih, H., Yang, T. \& Yang, Y. 2007. The type 2 dengue virus envelope protein interacts with small ubiquitin-like modifier-1 (SUMO-1) conjugating enzyme 9 (Ubc9). Journal of Biomedical Science 14(3): 429-444.

Datar, P.A. \& Jadhav, S.R. 2015. Design and synthesis of Pyrazole-3-one derivatives as hypoglycaemic agents. International Journal of Medicinal Chemistry 2015: 670181.

Du, Q.S., Wang, Q.Y., Du, L.Q., Chen, D. \& Huang, R.B. 2013. Theoretical study on the polar hydrogen- $\pi(\mathrm{Hp}-\pi)$ interactions between protein side chains. Chemistry Central Journal 7(1): 92

Duax, W.L., Thomas, J., Pletnev, V., Addlagatta, A., Huether, R., Habegger, L. \& Weeks, C.M. 2005. Determining structure and function of steroid dehydrogenase enzymes by sequence 
analysis, homology modeling, and rational mutational analysis Annals of the New York Academy of Sciences 1061: 135-148.

Erbel, P., Schiering, N., D'Arcy, A., Renatus, M., Kroemer, M., Lim, S.P., Zheng Yin, Z., Keller, T.H., Vasudevan, S.G. \& Hommel, U. 2006. Structural basis for the activation of flaviviral NS3 proteases from dengue and West Nile virus. Nature Structural \& Molecular Biology 13(4): 372-372.

Falgout, B., Pethel, M., Zhang, Y.M. \& Lai, C.J. 1991. Both nonstructural proteins NS2B and NS3 are required for the proteolytic processing of dengue virus nonstructural proteins. Journal of Virology 65(5): 2467-2475.

Frimayanti, N., Chee, C., Zain, S.M. \& Rahman, N.A. 2011. Design of new competitive dengue NS2B/NS3 protease inhibitors - A computational approach. International Journal of Molecular Sciences 12(2): 1089-1100.

Fukunishi, Y. \& Nakamura, H. 2011. Prediction of ligand-binding sites of proteins by molecular docking calculation for a random ligand library. Protein Science 20(1): 95-106.

Grinter, S.Z.\& Zou, X. 2014. Challenges, applications, and recent advances of protein-ligand docking in structure-based drug design. Molecules 19(7): 10150-10176.

Halstead, S.B. 2005. More dengue, more questions. Emerging Infection Disease 11(5): 740-741.

Heh, C.H., Othman, R., Buckle, M.J.C., Sharifuddin, Y., Yusof, R. \& Rahman, N.A. 2013. Rational discovery of dengue type 2 non-competitive inhibitors. Chemical Biology \& Drug Design 82(1): 1-11.

Heilman, J.M., Wolff, J.D., Beards, G.M. \& Basden, B.J. 2014. Dengue fever: A wikipedia clinical review. Open Medicine 8(4): 105-115.

Hetényi, C. \& van der Spoel, D. 2006. Blind docking of drugsized compounds to proteins with up to a thousand residues. FEBS Letters 580(5): 1447-1450.

Kadir, S.L.A., Yaakob, H. \& Zulkifli, R.M. 2013. Potential anti-dengue medicinal plants: A review. Journal of Natural Medicine 67(4): 677-689.

Kaptein, S.J.F., Burghgraeve, T.D., Froeyen, M., Pastorino, B., Alen, M.M.F., Mondotte, J.A., Herdewijn, P., Jacobs, M., de Lamballerie, X., Schols, D., Gamarnik, A.V., Sztaricskai, F. \& Neyts, J. 2010. A derivate of the antibiotic doxorubicin is a selective inhibitor of dengue and yellow fever virus replication in vitro. Antimicrobial Agents and Chemotheraphy 54(12): 5269-5280.

Kellenberger, E., Schalon, C. \& Rognan, D. 2008. How to measure the similarity between protein ligand-binding sites? Current Computer-Aided Drug Design 4: 209-220.

Kiat, T.S., Pippen, R., Yusof, R., Ibrahim, H., Khalid, N. \& Rahman, N.A. 2006. Inhibitory activity of cyclohexenyl chalcone derivatives and flavonoids of fingerroot, Boesenbergia rotunda (L.), towards dengue-2 virus NS3 protease. Bioorganic \& Medicinal Chemistry Letters 16(12): 3337-3340.

Kumar, C.V.M.N., Taranath, V., Venkatamuni, A., Vardhan, R.V., Prasad, Y.S., Ravi, U.\& Sai Gopal, D.V.R. 2015. Therapeutic potential of Carica papaya L. leaf extraction in treatment of dengue patients. International Journal of Applied Biology \& Pharmaceutical 6(3): 93-98.

Kyle, J.L. \& Harris, E. 2006. Global spread and persistence of dengue. Annual Review of Microbiology 62: 71-92.

Leung, D., Schroder, K., White, H., Fang, N.X., Stoermer, M.J., Abbenante, G., Martin. J.L., Young, P.R. \& Fairlie, D.P. 2001. Activity of recombinant dengue 2 virus NS3 protease in the presence of a truncated NS2B Co-factor, small peptide substrates, and inhibitors. Journal of Biological Chemistry 276(49): 45762-45771.

Lifson, S., Hagler, A.T. \& Dauber, P. 1979. Consistent force field studies of intermolecular forces in hydrogen-bonded crystals. 1. carboxylic acids, amides, and the $\mathrm{C}=\mathrm{O}-\mathrm{H}$ - hydrogen bonds Journal of American Chemical Society 101(11): 5111-5121.

Low, J.S., Wu, K.X., Chen, K.C., Ng, M.M. \& Chu, J.J. 2011. Narasin, a novel antiviral compound that blocks dengue virus protein expression. Antiviral Theraphy 16(12): 1203-1218.

Mustafa, M.S., Rasotgi, V., Jain, S. \& Gupta, V. 2015. Discovery of fifth serotype of dengue virus (DENV-5): A new public health dilemma in dengue control. Armed Forces Medical Services 71(1): 67-70.

Normile, D. 2013. Surprising new dengue virus throws a spanner in disease control efforts. Science 342(6157): 415.

Ong, S.Q. 2016. Dengue vector control in Malaysia: A review for current and alternative strategies. Sains Malaysiana 45(5): 777-785.

Othman, R., Kiat, T.S., Khalid, N., Yusof, R., Newhouse, I., Newhouse, J.S.,Alam, M.\& Rahman, N.A. 2008. Docking of noncompetitive inhibitors into dengue virus type 2 protease: Understanding the interactions with allosteric binding sites. Journal of Chemical Infornation and Modelling 48(8): 1582-1591.

van Panhuis, W.G., Gibbons, R.V., Endy, T.P., Rothman, A.L., Srikiatkhachorn, A., Nisalak, A., Burke, D.S. \& Cummings, D.A.T. 2010. Inferring the serotype associated with dengue virus infections on the basis of pre- and postinfection neutralizing antibody titers. Journal of Infectious Disease 202(7): 1002-1010.

Rothan, H.A., Bahrani, H., Mohamed,Z., Rahman, N.A. \& Yusof, R. 2014a. Fusion of Protegrin-1 and Plectasin to MAP30 shows significant inhibition activity against dengue virus replication. PLoS ONE 9(4): e94561.

Rothan, H.A., Mohamed, Z., Paydar, M., Rahman, N.A. \& Yusof, R. 2014b. Inhibitory effect of doxycycline against dengue virus replication in vitro. Archieves of Virology 159(2): 711-718.

Rothan, H.A., Buckle, M.J., Ammar, Y.A., Shatrah, P.M., Noorsaadah, A.R. \& Rohana, Y. 2013. Study the antiviral activity of some derivatives of tetracycline and non-steroid anti-inflammatory drugs towards dengue virus. Tropical Biomedicine 30(6): 1-10.

Sukupolvi-Petty, S., Austin, S.K., Purtha, W.E., Oliphant, T., Nybakken, G.E., Schlesinger, J.J., Roehrig, J.T., Gromowski, G.D., Barrett, A.D., Fremont, D.H. \& Diamond, M.S. 2007. Type- and subcomplex-specific neutralizing antibodies against domain III of dengue virus type 2 envelope protein recognize adjacent epitopes. Journal of Virology 81(23): 12816.

Sun, P. \& Kochel, T.J. 2013. The battle between infection and host immune responses of dengue virus and its implication in dengue disease pathogenesis. The Scientific World Journal 2013: 843469

Tomlinson, S.M., Malmstrom, R.D. \& Watowich, S.J. 2009. New approaches to structure-based discovery of dengue protease inhibitors. Infectious Disorders-Drug Targets 9(3): 327-343.

Wan-Norafikah, O., Nazni, W.A., Noramiza, S., Shafa'arKo'ohar, S., Heah, S.K., Nor-Azlina, A.H., Khairul-Asuad, M. \& Lee, H.L. 2012. Distribution of Aedes mosquitoes in three selected localities in Malaysia. Sains Malaysiana 41(10): 1309-1313.

Wang, W.K., Sung, T.L., Lee, C.N.,Lin, T.Y. \& King, C.C. 2002. Sequence diversity of the capsid gene and the nonstructural 
gene NS2B of dengue-3 virus in vivo. Journal of Virology 303(1): 181-191.

Zhang, X.G., Mason, P.W., Dubovi, E.J., Xu, X., Bourne, N., Renshawc, R.W., Blocka, T.M. \& Birka, A.V.2009. Antiviral activity of geneticin against dengue virus. Antiviral Research 83(1): 21-27.

Rufaidah Othman \& Saiful Anuar Karsani* Institute of Biological Sciences, Faculty of Science University of Malaya

50603 Kuala Lumpur, Federal Territory

Malaysia

\section{Rozana Othman}

Department of Pharmacy, Faculty of Medicine University of Malaya

50603 Kuala Lumpur, Federal Territory

Malaysia

Aida Baharuddin

Department of Biotechnology, Faculty of Science

Lincoln University College

47301 Petaling Jaya, Selangor Darul Ehsan

Malaysia

Nagasundara Ramanan Ramakrishnan

School of Engineering

Monash University Bandar Sunway

46150 Bandar Sunway, Selangor Darul Ehsan

Malaysia
Noorsaadah Abd. Rahman

Department of Chemistry, Faculty of Science

University of Malaya

50603 Kuala Lumpur, Federal Territory

Malaysia

Rohana Yusof

Department of Molecular Medicine, Faculty of Medicine

University of Malaya

50603 Kuala Lumpur, Federal Territory

Malaysia

Rohana Yusof

Drug Design and Development Research Group (DDDRG)

University of Malaya

50603 Kuala Lumpur, Federal Territory

Malaysia

*Corresponding author; email: saifule78@um.edu.my

Received: 28 July 2016

Accepted: 20 March 2017 